\title{
THE CIRCULATORY RESPONSE TO A STANDARD POSTURAL CHANGE IN ISCHÆMIC HEART DISEASE
}

\author{
BY \\ MICHAEL THOMAS AND JOHN SHILLINGFORD \\ From the Medical Research Council Cardiovascular Research Group, Department of Medicine, Postgraduate Medical \\ School of London \\ Received April 30, 1964
}

A direct hæmodynamic assessment of cardiac function in man is a desirable addition to a clinical appraisal of the cardiovascular system. Cardiac performance, however, involves many factors and while it is possible to analyse some of these in animal experiments, extensive investigations are not usually admissible in patients with ischæmic heart disease.

McMichael and Sharpey-Schafer (1944) showed in normal subjects that by changing the posture from the upright to recumbent position the cardiac output and stroke volume were raised. These observations have been used as a basis for a test of myocardial function in which changes of cardiac output are measured by dye dilution and the photoelectric earpiece technique.

The purpose of this paper is to describe such a test, to give the results when applied to normal subjects and to patients with ischæmic heart disease, and to discuss their significance in relation to the clinical findings.

\section{SubjeCts AND Methods}

Studies were carried out on 26 patients; 18 of these had suffered a myocardial infarction and 8 had no evidence of cardiovascular or debilitating disease. The ages are shown in the Table; with one exception those of the controls are comparable with those of the patients with ischæmic disease.

In most cases the ischæmic patients were convalescent following myocardial infarction and were undertaking only minor activities. In these, the investigation was made between two and six weeks after the acute episode. Two patients had recovered from infarction several months previously.

Of the patients with ischæmic heart disease, 11 had been in cardiac failure previously, but at the time of the investigation only 6 had clinical evidence of failure; 7 were receiving treatment with digitalis with or without a diuretic. The patients were in sinus rhythm.

A routine clinical examination, chest radiograph, and electrocardiogram were carried out in all patients.

The diagnosis of myocardial infarction was accepted on the basis of a typical history and electrocardiographic abnormality.

Two estimations of the cardiac output, pulse rate, and blood pressure were made with the patient resting quietly in a twenty degree feet down position on a tipping table. The position was then changed to the horizontal and the legs were raised to sixty degrees by means of a wooden support (Fig. 1A and B). Two further measurements of cardiac output, pulse rate, and blood pressure were then made at three-minute intervals, the first of these being made three minutes after the change of posture. Cardiac output was estimated by an indicator dilution technique (Taylor and Shillingford, 1959; Thomas, Malmcrona, and Shillingford, 1964) using the photoelectric earpiece.* A known quantity $(50 \mathrm{mg}$.) of Coomassie Blue dye was injected from a special syringe through a fine polythene cathetert inserted through a needle in the median antecubital vein and advanced into the great veins. The resultant dye dilution curve was calibrated in terms

\footnotetext{
* Cambridge Instrument Co.

$\uparrow$ PE60 Intramedic U.S.A.
}

C 


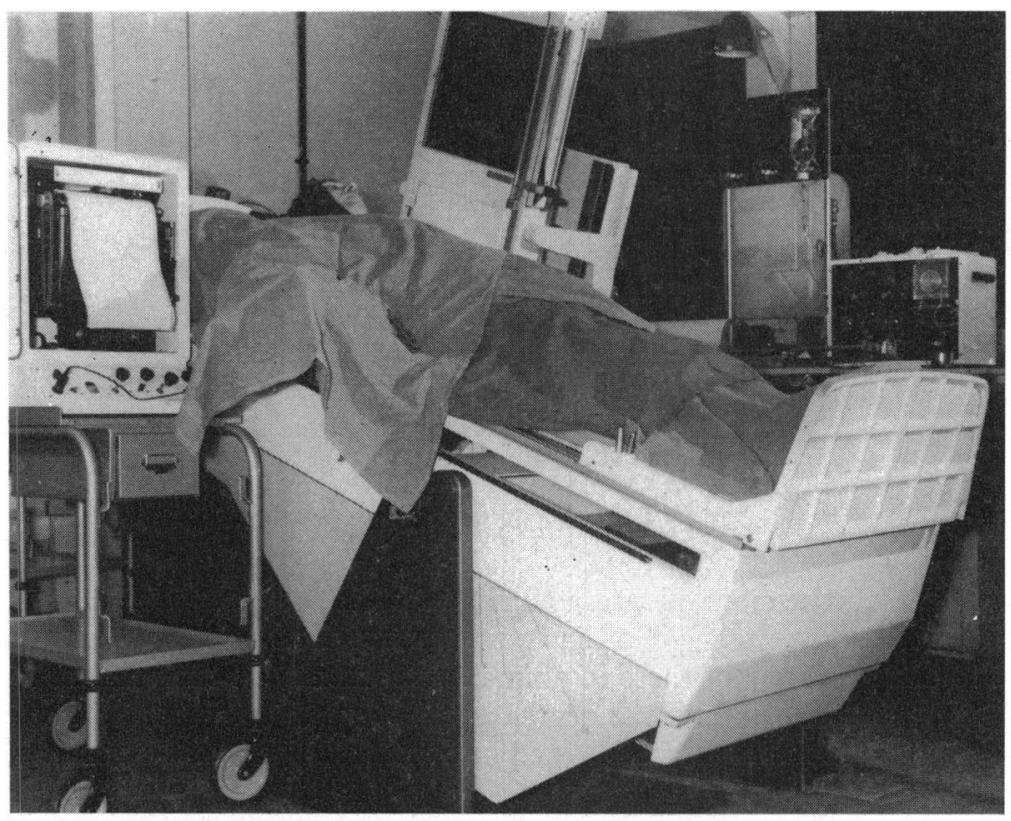

A

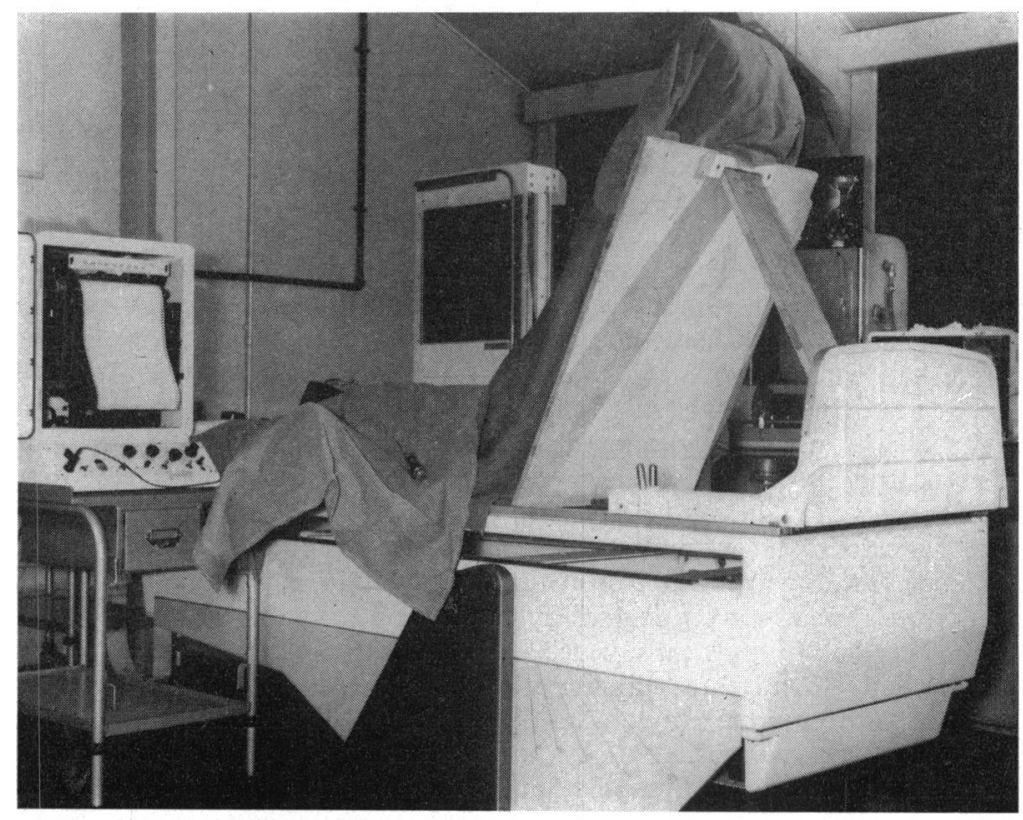

B

FIG. 1.-The two positions employed in the test. 
of dye concentration from a central venous blood sample taken three minutes after injection. Dye was extracted from the plasma and measured by spectrophotometry. Subsequent relative cardiac outputs were calculated according to the areas of the dye curves (Gabe, Tuckman, and Shillingford, 1962).

Heart rate at the moment of injection was recorded directly on the dye curve by using a slightly incomplete pulse rejection on the dye recorder.

Blood pressure was measured by sphygmomanometry in most cases but in some brachial artery pressures were recorded via a fine polythene catheter* introduced percutaneously by the Seldinger method (1953).

INITIAL

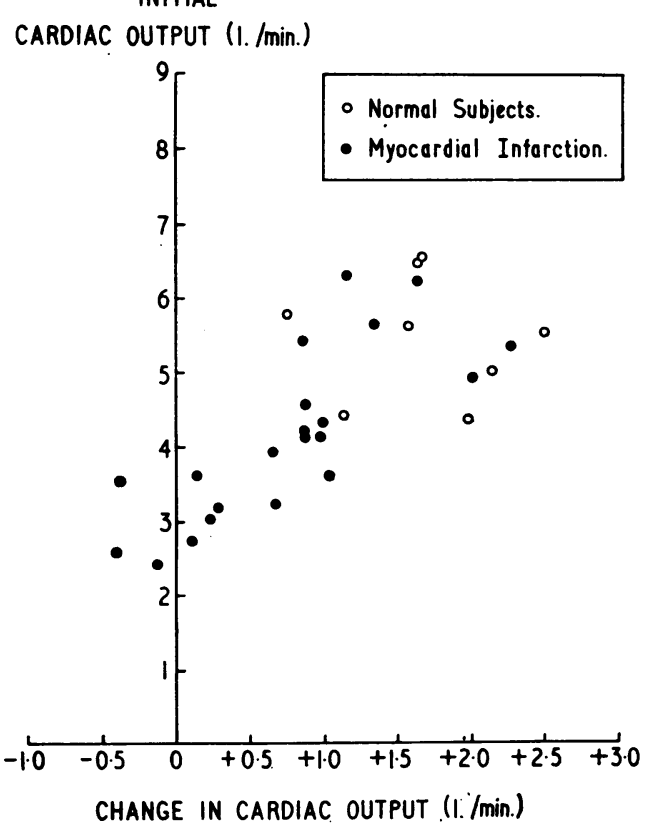

FIG. 2.-The relation between resting cardiac output and the change in cardiac output following the manœuvre.

\section{RESULTS}

Hamodynamic Changes. Figure 2 illustrates the changes in cardiac output that occurred in a group of non-hypertensive patients who had suffered a myocardial infarction, together with the response in eight normal subjects. In the twenty degree feet down position the range of resting cardiac output in the ischæmic patients was $2.61 . / \mathrm{min} .-6.31 . / \mathrm{min}$.; mean $4 \cdot 21 . / \mathrm{min}$. The mean cardiac output of the normal subjects was $5.51 . / \mathrm{min}$. (range $4.4-6.61 . / \mathrm{min}$.). There is a general relation between the resting cardiac output and the ability to respond to the manœuvre. Those with a low resting output were usually unable to increase it in the normal way. The contribution of stroke output and heart rate response is analysed in Fig. 3 and 4 . In those cases that had a fall in cardiac output the resting outputs were among the lowest measured.

Figure 2 shows the resting stroke outputs of the two groups and the stroke volume change that occurred after the change in position. The mean stroke output of the patients with myocardial infarction in the feet down position was $56 \mathrm{ml}$. That of the controls was $68 \mathrm{ml}$. Those with low resting stroke outputs were unable to increase it to the same degree as the normals. In general the lower the resting stroke output the less the increase after the change in position. More patients had a negative response in terms of stroke output than in terms of total cardiac output because compensatory tachycardia occurred to a variable extent.

* PE60 Intramedic U.S.A. 
INITIAL

STROKE OUTPUT (ml.)

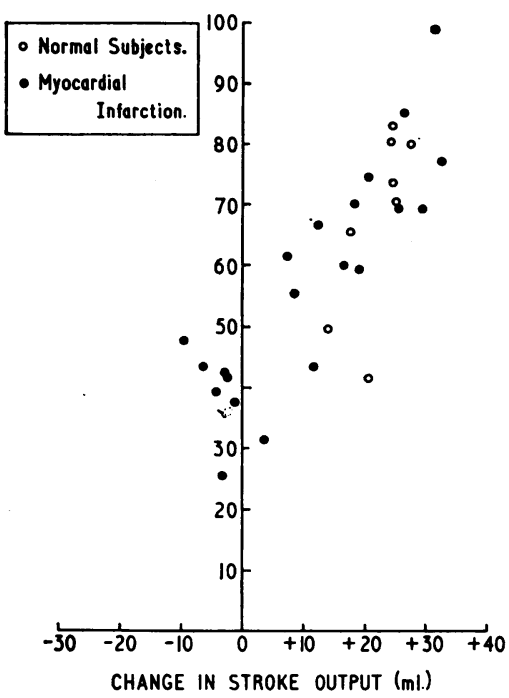

FIG. 3.-The relation between resting stroke output and the change in stroke output following the manœuvre.

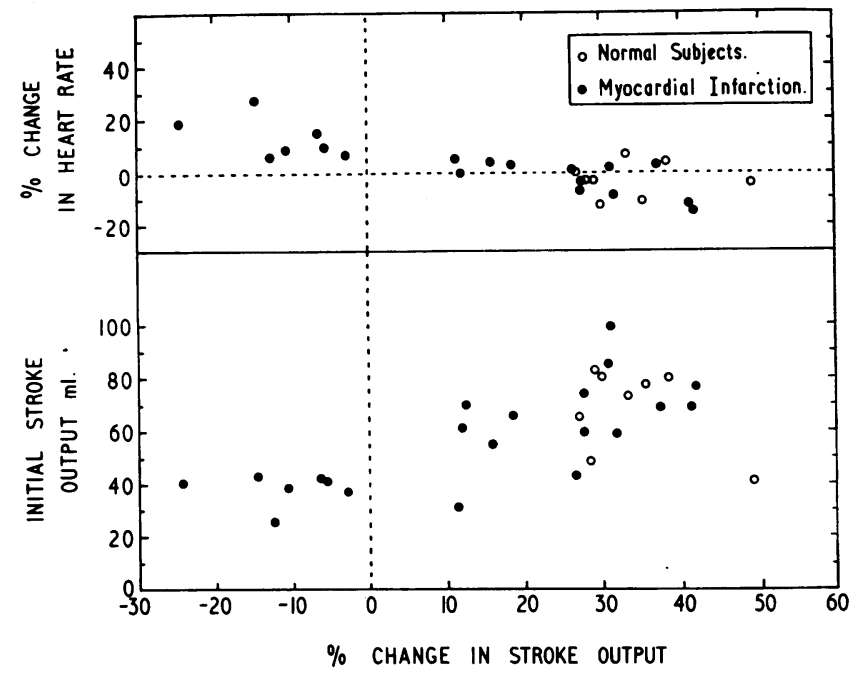

FIG. 4.-The response to the test in terms of heart rate and stroke output.

TABLE

Clinical and Hamodynamic Data of 8 Patients Without Evidence of Cardiovascular Disease and 18 Who Had SUfFered MYocardial INFARCTION

\begin{tabular}{|c|c|c|c|c|c|c|c|c|c|c|c|c|c|c|}
\hline $\begin{array}{l}\text { Patient } \\
\text { No., sex, } \\
\text { and age }\end{array}$ & Diagnosis* & $\begin{array}{l}\text { Heart } \\
\text { sounds }\end{array}$ & $\begin{array}{c}\text { Jugular } \\
\text { venous } \\
\text { pressure }\end{array}$ & $\begin{array}{c}\text { Cardio- } \\
\text { thoracic } \\
\text { ratio }\end{array}$ & $\begin{array}{l}\text { Cardiac } \\
\text { output } \\
\text { (1./min.) }\end{array}$ & $\begin{array}{c}\text { Cardiac } \\
\text { output } \\
\text { change } \\
(1 . / \text { min. })\end{array}$ & $\begin{array}{c}\text { Stroke } \\
\text { output } \\
\text { (ml.) }\end{array}$ & $\begin{array}{c}\text { Stroke } \\
\text { output } \\
\text { change } \\
\text { (ml.) }\end{array}$ & $\begin{array}{c}\text { Stroke } \\
\text { output } \\
\text { change } \\
(\%)\end{array}$ & $\begin{array}{c}\text { Heart } \\
\text { rate/min. } \\
\text { position } 1\end{array}$ & $\begin{array}{c}\text { Heart } \\
\text { rate/min. } \\
\text { position } 2\end{array}$ & $\begin{array}{c}\text { Heart } \\
\text { rate } \\
\text { change } \\
(\%)\end{array}$ & $\begin{array}{c}\text { B.P. } \\
\text { position 1 } \\
(\mathrm{mm} \text {. Hg) }\end{array}$ & $\begin{array}{c}\text { B.P. } \\
\text { position 2 } \\
(\mathrm{mm} . \mathrm{Hg})\end{array}$ \\
\hline $\begin{array}{lll}1 & \mathbf{M} & \mathbf{6 1} \\
2 & \mathbf{M} & 37 \\
3 & \mathbf{M} & 47 \\
4 & \mathbf{M} & 21 \\
5 & \mathbf{M} & 55 \\
6 & \mathbf{5} & 52 \\
7 & \mathbf{M} & 56 \\
8 & \mathrm{~F} & 49\end{array}$ & $\begin{array}{l}\text { P.R.I. } \\
\text { G.U. } \\
\text { N. } \\
\text { N. } \\
\text { G.U. } \\
\text { P.R.I. } \\
\text { N. } \\
\text { N. }\end{array}$ & $\begin{array}{l}\text { N. } \\
\mathbf{N} . \\
\mathbf{N} . \\
\mathbf{N} . \\
\mathbf{N} . \\
\mathbf{N} \\
\text { N. }\end{array}$ & $\begin{array}{l}\text { N. } \\
\text { N. } \\
\text { N. } \\
\text { N. } \\
\text { N. } \\
\text { N. } \\
\text { N. } \\
\text { N. }\end{array}$ & $\begin{array}{l}38 \cdot 4 \\
36 \cdot 1 \\
43 \cdot 5 \\
39 \cdot 6 \\
40 \cdot 3 \\
44 \cdot 7 \\
43 \cdot 1 \\
44 \cdot 7\end{array}$ & $\begin{array}{l}6 \cdot 5 \\
5 \cdot 8 \\
5 \cdot 0 \\
6 \cdot 6 \\
4 \cdot 4 \\
5 \cdot 5 \\
5 \cdot 7 \\
4 \cdot 5\end{array}$ & $\begin{array}{l}+1.6 \\
+0.8 \\
+2.1 \\
+1.7 \\
+2.0 \\
+2.5 \\
+1.6 \\
+1.1\end{array}$ & $\begin{array}{l}71 \\
81 \\
74 \\
83 \\
80 \\
42 \\
66 \\
50\end{array}$ & $\begin{array}{l}+25 \\
+24 \\
+25 \\
+24 \\
+27 \\
+21 \\
+18 \\
+14\end{array}$ & $\begin{array}{l}+36 \\
+30 \\
+33 \\
+29 \\
+38 \\
+49 \\
+37 \\
+28\end{array}$ & $\begin{array}{r}98 \\
70 \\
70 \\
74 \\
57 \\
135 \\
71 \\
90\end{array}$ & $\begin{array}{r}88 \\
62 \\
75 \\
72 \\
60 \\
129 \\
71 \\
87\end{array}$ & $\begin{array}{c}-10 \\
-11 \\
+7 \\
+2 \\
+4 \\
-4 \\
0 \\
-3\end{array}$ & $\begin{array}{l}170 / 90 \\
136 / 80 \\
150 / 96 \\
138 / 80 \\
110 / 60 \\
123 / 85 \\
120 / 90 \\
170 / 100\end{array}$ & $\begin{array}{l}154 / 90 \\
134 / 78 \\
150 / 100 \\
140 / 80 \\
110 / 60 \\
127 / 93 \\
127 / 93 \\
170 / 100\end{array}$ \\
\hline Mean 47 & & & & & $5 \cdot 5$ & & 68 & & & 83 & & & & \\
\hline 9 F 66 & M.I. & & N. & 46.9 & $3 \cdot 3$ & +0.7 & 32 & +4 & +11 & 100 & 105 & +5 & $170 / 100$ & - \\
\hline $\begin{array}{lll}10 & \text { M } & 39 \\
11 & \mathrm{~F} & 59\end{array}$ & $\begin{array}{l}\text { M.I. } \\
\text { M.I. } \\
\text { M.I. }\end{array}$ & $\begin{array}{l}\text { Third } \\
\text { Third } \\
\text { Third }\end{array}$ & $\begin{array}{l}\text { Raised } \\
\text { Raised } \\
\text { Raised }\end{array}$ & $\begin{array}{l}52 \cdot 8 \\
54 \cdot 7 \\
64 \cdot 0\end{array}$ & $\begin{array}{l}3.2 \\
2.5 \\
3.6\end{array}$ & $\begin{array}{l}+0.3 \\
-0.1 \\
-0.4\end{array}$ & $\begin{array}{l}43 \\
26 \\
41\end{array}$ & $\begin{array}{l}-6 \\
-3 \\
-10\end{array}$ & $\begin{array}{l}-15 \\
-13 \\
-24\end{array}$ & $\begin{array}{l}74 \\
96 \\
86\end{array}$ & $\begin{array}{r}94 \\
102 \\
102\end{array}$ & $\begin{array}{l}+27 \\
+6 \\
+19\end{array}$ & $\begin{array}{l}150 / 90 \\
130 / 100 \\
150 / 90\end{array}$ & $\begin{array}{l}148 / 110 \\
130 / 100\end{array}$ \\
\hline $\begin{array}{l}12 \text { M } 72 \\
13 \text { M } 60 \\
14 \\
15 \\
15\end{array}$ & $\begin{array}{l}\text { M.I. } \\
\text { M.I. } \\
\text { M.I. } \\
\text { M.I. } \\
\text { M.I. }\end{array}$ & $\begin{array}{l}\text { N. } \\
\text { N. } \\
\text { N. } \\
\text { N. } \\
\text { Third }\end{array}$ & $\begin{array}{l}\text { N. } \\
\text { N. } \\
\text { N. } \\
\text { N. }\end{array}$ & $\begin{array}{l}\frac{54 \cdot 6}{\overline{5}} \\
\frac{51 \cdot 5}{48 \cdot 3}\end{array}$ & $\begin{array}{l}3 \cdot 6 \\
5 \cdot 4 \\
4 \cdot 2 \\
6 \cdot 25 \\
3 \cdot 6\end{array}$ & $\begin{array}{l}+1.0 \\
+2.2 \\
+0.9 \\
+1.6 \\
+0.1\end{array}$ & $\begin{array}{l}43 \\
69 \\
60 \\
70 \\
42\end{array}$ & $\begin{array}{l}+12 \\
+26 \\
+19 \\
+30 \\
-2\end{array}$ & $\begin{array}{l}+27 \\
+37 \\
+32 \\
+43 \\
-6\end{array}$ & $\begin{array}{l}80 \\
76 \\
72 \\
81 \\
90\end{array}$ & $\begin{array}{l}81 \\
78 \\
66 \\
72 \\
99\end{array}$ & $\begin{array}{l}+1 \\
+3 \\
+8 \\
-11 \\
+10\end{array}$ & $\begin{array}{l}140 / 80 \\
130 / 60 \\
156 / 90 \\
168 / 94 \\
85 / 60\end{array}$ & $\begin{array}{l}150 / 80 \\
125 / 80 \\
170 / 90 \\
172 / 98 \\
-\end{array}$ \\
\hline $\begin{array}{lll}16 & \ddot{M} & 65 \\
17 & M & 49 \\
18 & M & 70 \\
19 & F & 48 \\
20 & M & 64 \\
21 & F & 60\end{array}$ & $\begin{array}{l}\text { M.I. } \\
\text { M.I. } \\
\text { M.I. } \\
\text { M.I. } \\
\text { M.I. } \\
\text { M.I. } \\
\text { M.I. }\end{array}$ & $\begin{array}{l}\text { N. } \\
\text { N. } \\
\text { N. } \\
\text { N. } \\
\text { N. } \\
\text { Third } \\
\text { Pre- } \\
\text { syst }\end{array}$ & $\begin{array}{l}\text { N. } \\
\text { N. } \\
\text { N. } \\
\text { N. } \\
\text { N. } \\
\text { N. } \\
\text { N. }\end{array}$ & $\begin{array}{l}42 \cdot 7 \\
48 \cdot 6 \\
46.4 \\
54 \cdot 0 \\
52 \cdot 2 \\
52 \cdot 7 \\
55 \cdot 9\end{array}$ & $\begin{array}{l}4 \cdot 2 \\
5 \cdot 7 \\
6 \cdot 3 \\
4 \cdot 2 \\
4 \cdot 6 \\
3 \cdot 0 \\
5 \cdot 4\end{array}$ & $\begin{array}{l}+0.9 \\
+1.33 \\
+1.2 \\
+1.0 \\
+0.9 \\
+0.2 \\
+0.9\end{array}$ & $\begin{array}{l}55 \\
77 \\
99 \\
74 \\
60 \\
42 \\
62\end{array}$ & $\begin{array}{l}+9 \\
+32 \\
+31 \\
+21 \\
+17 \\
+3 \\
+7\end{array}$ & $\begin{array}{l}+16 \\
+42 \\
+31 \\
+28 \\
+27 \\
+6 \\
+12\end{array}$ & $\begin{array}{l}76 \\
80 \\
61 \\
54 \\
74 \\
63 \\
90\end{array}$ & $\begin{array}{l}79 \\
69 \\
62 \\
52 \\
69 \\
73 \\
90\end{array}$ & $\begin{array}{l}+4 \\
-15 \\
+2 \\
-4 \\
-7 \\
+15 \\
0\end{array}$ & $\begin{array}{l}130 / 80 \\
11482 \\
110 / 66 \\
170 / 95 \\
163 / 104 \\
155 / 93 \\
130 / 70\end{array}$ & $\begin{array}{l}125 / 80 \\
110 / 70 \\
180 / 100 \\
180 / 123 \\
155 / 93 \\
132 / 80\end{array}$ \\
\hline $\begin{array}{lll}22 & M & 54 \\
23 & M & 48 \\
24 & M & 64 \\
25 & M & 40\end{array}$ & $\begin{array}{l}\text { M.I. } \\
\text { M.I. } \\
\text { M.I. } \\
\text { M.I. }\end{array}$ & $\begin{array}{l}\text { N. } \\
\text { Third } \\
\text { Third } \\
\text { Pre- } \\
\text { syst. }\end{array}$ & $\begin{array}{l}\text { N. } \\
\text { Raised } \\
\text { Raised } \\
\text { N. }\end{array}$ & $\begin{array}{l}43 \cdot 3 \\
60 \cdot 6 \\
41 \cdot 9\end{array}$ & $\begin{array}{l}4 \cdot 4 \\
2 \cdot 8 \\
2.6 \\
3.9\end{array}$ & $\begin{array}{l}+1.0 \\
+0.1 \\
-0.4 \\
+0.7\end{array}$ & $\begin{array}{l}66 \\
37 \\
39 \\
70\end{array}$ & $\begin{array}{l}+12 \\
-1 \\
-4 \\
+18\end{array}$ & $\begin{array}{l}+18 \\
-3 \\
-11 \\
+13\end{array}$ & $\begin{array}{l}68 \\
75 \\
67 \\
57\end{array}$ & $\begin{array}{l}70 \\
80 \\
73 \\
59\end{array}$ & $\begin{array}{l}+3 \\
+7 \\
+9 \\
+4\end{array}$ & $\begin{array}{l}140 / 96 \\
110 / 80 \\
108 / 65 \\
120 / 80\end{array}$ & $\begin{array}{l}154 / 94 \\
118 / 90 \\
100 / 70 \\
120 / 80\end{array}$ \\
\hline $26 \mathrm{M} 62$ & M.I. & N. & N. & $39 \cdot 1$ & $5 \cdot 0$ & $+2 \cdot 0$ & 85 & +26 & +31 & 59 & 63 & +7 & $150 / 90$ & $160 / 90$ \\
\hline Mean 57 & & & & & $4 \cdot 2$ & & 56 & & & 62 & & & & \\
\hline
\end{tabular}

* M.I.= Myocardial infarct; P.R.I = Post-respiratory infection; G.U.=Gastric ulcer; N.=Normal. 
The change in heart rate following the manœuvre is shown in Fig. 4. The mean heart rate of the controls was 83 a minute and that of the ischæmic patients 62 a minute. For comparison the heart rate change is expressed as a percentage of the initial figure. Those with a normal response in terms of cardiac output and stroke output either achieve this at the same heart rate or in the presence of a bradycardia. In those with a moderately impaired stroke response the behaviour of the heart rate was not greatly different from the controls but in no case did a bradycardia occur. Those in whom stroke output fell responded in some instances with a marked tachycardia but in spite of this the total output remained of the same order as in the feet down position.

The patients in whom a fall in stroke output was seen were receiving digitalis.

Blood Pressure. All the data shown in the diagrams are taken from investigation of patients with a blood pressure below $170 / 100 \mathrm{~mm}$. $\mathrm{Hg}$ during the test. In general the blood pressure changes are small and insignificant in normotensives (see Table).

Relation of Hamodynamic Findings to the Clinical Picture. The auscultatory signs and presence or absence of a raised jugular venous pressure in the patients studied are shown in Fig. 5. A phonocardiographic confirmation of the abnormal heart sounds was made during the hæmodynamic investigation. Several of the patients with myocardial infarction had normal heart sounds without added sounds and all those showed an entirely normal response to the test. Three patients with persistent presystolic sounds were investigated. These had a moderately impaired response. In those who responded with a fall in stroke output an obvious third sound was constantly present.

Five of the patients had raised jugular venous pressure at the time of the test, and these all showed a fall in stroke output on change of position. Five others had had a rise at some time and these had some impairment of response with one exception. The circulation in this patient behaved normally as judged by the investigation three weeks after an acute infarction associated with overt cardiac failure. At the time of the test clinical signs in this patient were normal and the only treatment was $0.25 \mathrm{mg}$. digoxin daily.

One of the patients who had a fall in stroke volume had a selective left heart failure with pulmonary œdema but without raised jugular venous pressure.

INITIAL

STROKE OUTPUT (ml.)

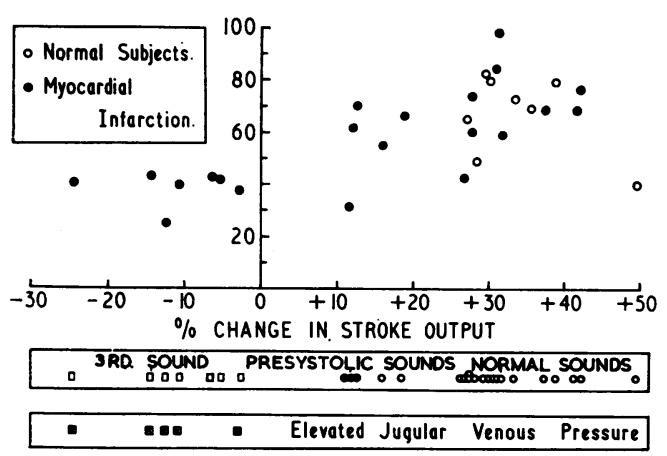

FIG. 5.-A diagrammatic representation of the physical signs in relation to the stroke output response to the test.

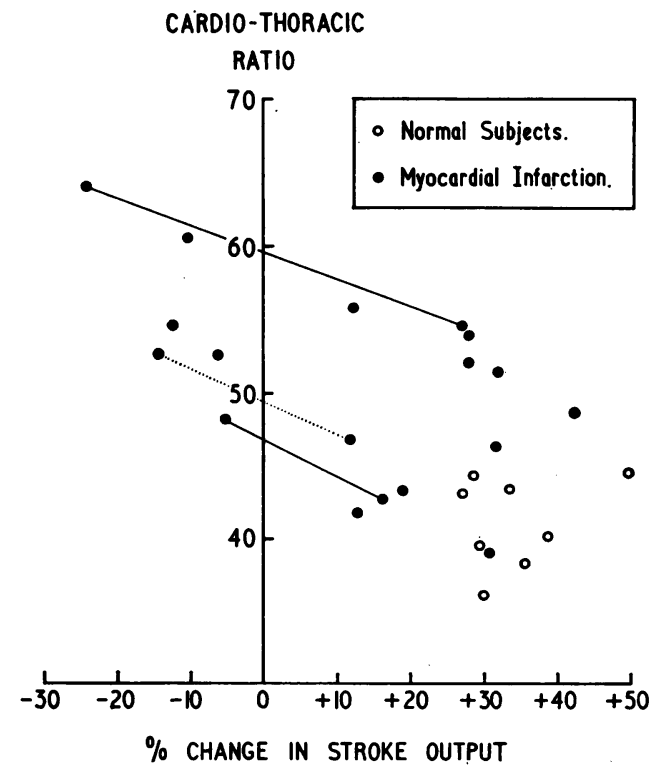

FIG. 6.-The stroke output response to the test related to heart size. The continuous lines represent the result of successful treatment of cardiac failure. The interrupted line illustrates deterioration after myocardial infarction. 


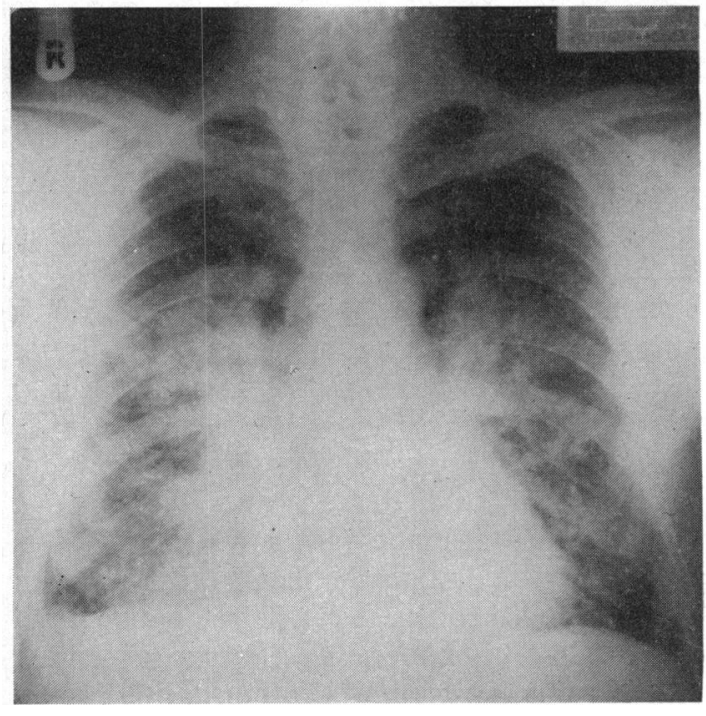

A

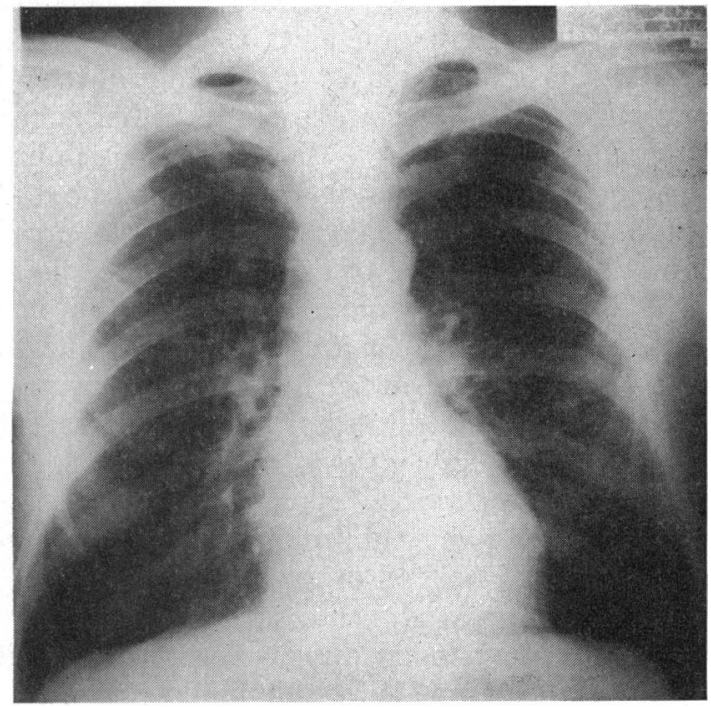

B

Frg. 7.-Radiographs of a patient referred to in the text. The stroke output response while in overt heart failure (A) was -6 per cent and after treatment (B) was +16 per cent.

Correlation with Radiological Appearances. Where possible a routine six-foot postero-anterior standing chest radiograph was taken within one week of the test. In three patients this was not obtained. As an indirect index of cardiac size the cardiothoracic ratio was calculated from the maximum width of the heart divided by the maximum width of the chest measured from the inner borders of the ribs. This ratio has been plotted against the percentage change in stroke output (Fig. 6). All the normal subjects had a cardiothoracic ratio of less than 45. Some of the patients with myocardial infarction had a normal heart size and these had an entirely normal response. On the other hand some ischæmic patients with a normal response had a slightly enlarged heart. An enlarged heart was not incompatible with a normal response, but all those who had a fall in stroke output had hearts among the largest measured. In terms of volume these were probably very much larger than those with a somewhat increased cardiothoracic ratio.

Two patients were investigated before and after effective treatment for cardiac failure. The continous lines in Fig. 6 show the subsequent change in circulatory response from a fall in stroke output to a rise in response to the test. In both instances this was associated with a decrease of heart size seen on serial radiographs and the loss of the third heart sound. One of these patients had a mainly left heart failure without a rise in jugular venous pressure. The chest radiographs showing pulmonary œdema at the time of the first test when the stroke response was -6 per cent and the appearance at the time of the second test when the stroke increased 16 per cent are illustrated in Fig. 7.

Another patient was studied before and after a myocardial infarction. She had had one infarction one year before the first investigation when she was found to have a moderately defective stroke response of +11 per cent. A further acute infarction occurred three weeks after the first study. This was associated with congestive heart failure with cardiac enlargement, a raised jugular venous pressure, and a third heart sound. Response to treatment was limited and the physical signs when later investigated included a raised jugular venous pressure and a third heart sound. On this occasion the stroke output fell 15 per cent and the heart rate rose by 27 per cent. The results are indicated by an interrupted line in Fig. 6.

Electrocardiography. Serial electrocardiograms were taken on all patients treated in the hos- 
pital during the acute stage. These showed the usual evolution of the acute injury pattern. Pathological $\mathrm{Q}$ waves were present in 5 patients. Of these, 3 had a very poor response to the test including a fall in stroke volume and 2 were entirely normal; 1 of these 2 was in cardiac failure during the acute episode. By the time of the test three weeks later, the jugular venous pressure had become normal, the third sound had gone and the heart had returned to an almost normal size. The only treatment continued was $0.25 \mathrm{mg}$. digoxin daily.

No relation was found between the electrocardiographic picture and the performance in the test.

\section{Illustrative CASE Histories}

Case 1. M.W. is a 46-year-old man (weight $88 \mathrm{~kg}$.) who had had a myocardial infarction in 1960 , from which he had completely recovered. Following this he had no angina of effort and was able to play tennis. On June 28, 1963 he was admitted with acute central chest pain extending to the neck and the left arm. There were no symptoms of left ventricular failure. He was in sinus rhythm; blood pressure was 140/80 mm. Hg. Jugular venous pressure was normal. A soft third heart sound was present. There were no other abnormal physical signs. The electrocardiogram showed pathological $Q$ waves and inverted $T$ in sII, sIII, and aVF. Chest radiograph was normal.

After admission his blood pressure fell progressively to $75 / 50 \mathrm{~mm}$. $\mathrm{Hg}$. This was treated with metaraminol, intramuscularly, $10 \mathrm{mg}$. (6 injections), by raising the foot of the bed, and with oxygen by mask. Blood pressure rose, the third sound was lost, and further recovery was uneventful.

Two weeks later he was investigated in the way described. The cardiac output was $6.331 . / \mathrm{min}$. Stroke output was $99 \mathrm{ml}$. in the initial position, and increased by 31 per cent when the position was changed.

He remains well, has no angina, and has normal exercise tolerance.

Case 2. M.R. is a 66-year-old woman (weight $53 \mathrm{~kg}$.) who had had a myocardial infarction in 1962 and in March 1963. Left ventricular failure and pulmonary œdema associated with the second infarction had responded to treatment with digitalis, diuretics, and salt restriction. Three weeks after infarction, chest radiograph showed that the pulmonary œdema had cleared and that the heart was only slightly enlarged. At that time she was in sinus rhythm; blood pressure was $160 / 100-110 \mathrm{~mm}$. Hg. Jugular venous pressure was normal. A presystolic heart sound was present. When investigated the cardiac output was 3.31./min.; stroke output was $32 \mathrm{ml}$. in the feet down position, and the stroke response to the change in position was +11 per cent.

She continued to be dyspnœic on moderate effort and left hospital on digoxin $0.25 \mathrm{mg}$. daily.

On May 29, 1963 she was readmitted. She gave a history of dyspnœa which had become increasingly easily provoked until it was present all the time, worse at night, and improved by sitting up. She had a cough productive of white frothy sputum. She had had no angina.

Examination revealed an ill patient, cyanosed, and dyspnœic at rest. She had a sinus tachycardia 110 a minute; blood pressure was $180 / 110 \mathrm{~mm}$. Hg. Jugular venous pressure was raised $4 \mathrm{~cm}$. above the sternal angle. The heart was enlarged; presystolic and third sounds were present. Widespread crepitations were heard at both lung bases; the liver was enlarged and tender; minimal œdema was present. The electrocardiogram indicated extension of the previous infarction. Chest radiograph showed an enlarged heart, pulmonary venous distension, and pulmonary œdema. Response to treatment was limited. Jugular venous pressure was $+2 \mathrm{~cm}$., the third sound remained, and the heart did not return to its previous size.

When investigated two weeks later the cardiac output was $3.21 . / \mathrm{min}$., stroke output $43 \mathrm{ml}$., and in response to the change in position the stroke output fell 15 per cent. She remained disabled.

Case 3. J.W. was a 42-year-old man with recurrent severe angina who first had a myocardial infarction in 1961 . He was admitted on July 7, 1963 with an unusually severe chest pain and a history of increasing dyspnœa. He had been unable to sleep at night on account of pain.

He was in sinus rhythm at 80 a minute; blood pressure was $120 / 80 \mathrm{~mm}$. Hg. Jugular venous pressure was normal. The apex beat was impalpable. There were no abnormal respiratory signs. The electrocardiogram showed left bundle-branch block. Chest radiograph showed an enlarged heart with gross pulmonary œdema (Fig. 7A). A third heart sound appeared on the day of investigation when cardiac output was 3.6 1./min. Stroke output was $42 \mathrm{ml}$., and the response to the change in position was a 6 per cent fall in stroke output.

Following rigorous therapy he improved slowly, the third heart sound was lost, the heart became smaller and the chest radiograph (Fig. 7B) showed clearing of the lung fields. 
The results of a further investigation were: cardiac output $4 \cdot 21 . / \mathrm{min}$., stroke output $55 \mathrm{ml}$., and a 16 per cent increase in stroke output in response to the change in position.

After the patient left hospital his exercise tolerance was limited by angina.

\section{DisCUSSION}

The body positions used were chosen on several counts. The 20 degree feet down position is not subject to the wider spontaneous variation in cardiac output found in more vertical positions. This variation at steeper angles is probably due to the patient's muscular effort needed for support unless he is held in a complex way. With greater degrees of tilt, especially if the patient is supported, venous pooling occurs and vasovagal syncope can result. In the 20 degree feet down position these problems do not exist to an important extent. The angle between the positions is small and the possibility of complication by postural reflexes is minimized.

The precise nature of the physiological stimulus involved in the test and which is responsible for the increase in cardiac output is neither easy to define nor investigate. Measurement of the right atrial pressure in normal subjects during the change in position shows a momentary rise and then a return to the previous level. Small differences in effective filling pressure which may be very important in ventricular filling are difficult to measure on account of the change in reference point. Direct measurement of the inferior vena cava blood flow in normal subjects (Pentecost, Irving, and Shillingford, 1963) has shown that the flow is related to body position-being low in the feet down position and high in the feet up position. It is likely that the effective filling pressure of the blood flowing into the heart is dependent on several factors, including the ability of the heart to deal with the blood returning from the body and the tone of the veins. Pressure volume relations in both the great veins and the pulmonary veins probably vary according to the degree of myocardial failure, and it is difficult to assess the contribution of any one factor to the pressure at a given point in a particular instance.

The mechanism of the tachycardia that occurs in patients who decrease stroke output when manœuvred in the way described is not clear. Most of these patients have a raised jugular venous pressure and abnormally distended systemic veins. It is possible that a further increase of systemic venous distension provokes a reflex increase of cardiac sympathetic tone and cardiac acceleration. The original observation of Bainbridge (1915) was that rapid intravenous injection of saline or defibrinated blood into anæsthetized dogs caused an acceleration of the heart rate without any consistent change in arterial blood pressure or respiration. He regarded the acceleration as a reflex initiated by a rise in pressure in the superior vena cava and right atrium because it was eliminated by cervical vagotomy. Attempts to reproduce the phenomenon, however, have shown very variable results. A wide variety of fluids has been infused under different experimental circumstances. Even when fresh venous blood from the same species was infused the results were variable (Aviado et al., 1951).

It was notable that, of the patients studied who had a fall in stroke volume and a tachycardia, one had no detectable increase in jugular venous pressure. In this patient, on the other hand, the radiological appearance of extreme pulmonary œdema (Fig. 7A) suggested a high pulmonary venous pressure. This raises the possibility of an afferent reflex limb arising in the lungs or pulmonary venous system. Receptors at this site were suggested by Daly et al. (1937) and further evidence of receptors in the pulmonary vein has been given by Aviado et al. (1951). These were shown to be concerned with a reflex respiratory response to raised pulmonary venous pressure and with profound circulatory reflexes during the infusion of veratrine. As yet the role of the receptors in other than experimental physiology is not clear.

An increase in heart rate seems to be a suitable response when the heart is unable to deal with a filling overload by an increase in stroke volume. The rate increase results in a somewhat higher cardiac output from the defective heart but this does not approach the level seen when normal stroke response is possible. Sarnoff et al. (1960) have shown that stimulation of the stellate ganglion in dogs results in an increased atrial contraction and resultant increase in ventricular filling. The 
external work for any given mean atrial pressure or any given end-diastolic pressure was increased. If the increase in heart rate observed in patients under conditions of diastolic overload reflects an increase in sympathetic drive to the heart, this is also a direct assistance to ventricular function.

A full analysis of the ventricular fault in failing to increase stroke output in the usual way is not possible in ischæmic patients at the present time. Experimental work in animals and man indicates that the important ventricular response to exercise, apart from tachycardia, is a more complete systolic ejection. Early measurement of the left ventricular diameter by means of variable inductance gauges installed within the ventricular chamber in unanæsthetized dogs showed that the typical response to exertion was a reduction in systolic diameter with little change in diastole (Rushmer, 1954). Later investigations (Rushmer and West, 1957) indicated that the response was in fact variable and that different degrees of diastolic relaxation, extent of systolic ejection, intraventricular pressure changes and heart rate response are possible. The change from sitting to recumbent in terms of stroke volume is mainly achieved by an increased degree of systolic ejection. Recently a decrease of end-diastolic and end-systolic ventricular dimensions in men exercising in the supine position has been demonstrated (Harrison et al., 1963). The changes were thought to approximate to one-half of the resting stroke volume.

The enlarged ischæmic heart is partially replaced by fibrous tissue; this deprives it of effective muscular bulk, impairs the function of that remaining, and alters the elasticity and compliance. Increase in heart size may be due to stretching of fibrous muscle walls and to the adoption of a more effective end-diastolic fibre length by the remaining muscle. Exaggeration of the disease in one place can result in functional or anatomical aneurysm. Hypertrophic changes can occur when survival is over a sufficient period of time (Mitchell and Schwartz, 1963).

Of the patients studied, those whose stroke output fell when subjected to the test were the ones that had the largest hearts as judged by radiological appearances. It is unlikely that ventricles diseased to this extent can vary the end-systolic point following the increase in filling load, but this may be difficult to investigate as at large ventricular volumes a much smaller decrease in cavity radius is required for a given change in stroke volume.

The possibility that incompetence of an atrio-ventricular valve was responsible for a reduction in forward stroke output when the filling load was increased must be considered. That this can be the explanation of an apparent falling off in ventricular performance when the filling pressure is increased to an extreme was indicated by Sarnoff and Berglund (1954). The significance of this with respect to tricuspid incompetence in human heart failure was discussed by McMichael and Shillingford (1957). While this may have contributed to the behaviour of those patients who showed a fall in stroke output in response to the test, atrio-ventricular valve incompetence was insufficient to be clinically evident.

The manœuvre shows whether the heart can respond in terms of stroke volume to a small change in the position of the body. The role of the stroke output change in circulatory adaptation to normal activity is as yet subject to discussion. Experimental work by Rushmer (1959) in dogs with chronically indwelling catheters showed that the ventricular chambers were frequently maximally dilated while the dogs were relaxed and recumbent. Stroke volume approached maximal values under these conditions. On sitting or standing the heart diminished in size and the stroke output was reduced. However, during exertion the stroke volume increased only a little and rarely exceeded recumbent control values. The slightly increased stroke volume was generally achieved by increased systolic ejection rather than diastolic distension. Studies in man of the circulatory response in terms of heart rate and stroke volume in health and in heart disease are not easily compared owing to the variety of body positions employed. The volume of the heart in man is larger in the supine than in the erect position (Larsson and Kjellberg, 1948); that this may influence the exercise response was suggested by Holmgren (1956). Reeves et al. (1961) considered that the dynamics during treadmill and supine exercise were so different as not to be comparable. This possibility, however, does not fully explain the diversity of results obtained. Chapman, Fisher, and Sproule (1960) found that stroke output was responsible for a large part of the increase in cardiac output occurring 
on exercise both in the erect and supine positions. Likewise, Mitchell, Sproule, and Chapman (1958) in a previous study show a major contribution from increased stroke output during exercise in the upright position. Other work by Donald et al. (1955), Barratt-Boyes and Wood (1957), and Holmgren, Jonsson, and Sjöstrand (1960) concerning the normal cardiac response to exercise in the supine position suggests that an increase in stroke output plays little or no part.

The response to exercise in patients who have recovered from a myocardial infarction was studied by Chapman and Fraser (1954). No difference in terms of cardiac output between normal subjects and cardiac patients was found, but a given cardiac output was attained at a higher heart rate and correspondingly lower stroke output in the case of those who had had an infarction. Malmcrona, Cramer, and Varnauskas (1963) in a more recent study similarly found no difference between cardiac output reached during exercise by normal subjects and patients who had suffered a myocardial infarction. They also found that in the ischæmic patients the tachycardia during exercise was more pronounced and, unlike the normal subjects, they failed to increase stroke output. The investigation was performed with patients in the sitting position. These authors regarded the failure to increase stroke output as evidence of myocardial failure. Bickelmann, Lippschutz, and Weinstein (1963) also found this hæmodynamic pattern in patients with unselected heart disease during work on a bicycle ergometer.

While circulatory response to exercise in healthy men and patients with myocardial disease awaits further definition, it can be accepted that there is an adjustment of stroke volume according to the position of the body in space. Unless the heart can achieve a normal stroke output for a given position the response to exercise in terms of cardiac output will be defective unless a compensatory tachycardia occurs. It is probable that the basic functional defect in the response of the heart to exercise after myocardial infarction is an initially low stroke output and an inability to increase this on demand. There is no known defect in heart rate response to exercise after myocardial infarction. In fact the tachycardia is more pronounced.

The manœuvre here described gives a wide range of stroke response in the ischæmic patients studied. The degree of response correlates well with physical signs and clinical features. It is a small demand that can be met after minor cardiac damage but not when this becomes more severe. It probably reflects the residual functional defect in patients who have suffered a myocardial infarction and have not necessarily overt signs of cardiac failure.

\section{SUMMARY}

The response of the circulation to a change in posture has been studied in normal subjects and patients with ischæmic heart disease. Measurements of cardiac output, stroke output, heart rate, and blood pressure were made.

The normal response to the test involves an increase in cardiac output mainly due to an increase in stroke output. Heart rate and blood pressure show little change. After myocardial infarction many patients are unable to respond normally and in some the cardiac output and stroke output may fall. When the stroke output falls a marked increase in heart rate may occur.

The hæmodynamic measurements have been related to the clinical picture, and the significance of the results with respect to cardiac performance during normal activity is discussed.

The authors wish to thank Dr. J. P. D. Mounsey for permission to study some of his patients. They are indebted to Mrs. Ann Simmonds and Miss Diana Cuttriss for technical assistance and to Sister Jean Child and the Nursing Staff; Miss Jean Powell drew the diagrams.

\section{REFERENCES}

Aviado, D. M., Li, T. H., Kalow, W., Schmidt, C. F., Turnbull, G. L., Peskin, G. W., Hess, M. E., and Weiss, A. J. (1951). Respiratory and circulatory reflexes from the perfused heart and pulmonary circulation of the dog. Amer. J. Physiol., 165, 261.

Bainbridge, F. A. (1915). The influence of venous filling upon the rate of the heart. J. Physiol. (Lond.), $50,65$.

Barratt-Boyes, B. G., and Wood, E. H. (1957). Hemodynamic response of healthy subjects to exercise in the supine position while breathing oxygen. J. appl. Physiol., 11, 129. 
Bickelmann, A. G., Lippschutz, E. J., and Weinstein, L. (1963). The response of the normal and abnormal heart to exercise. A functional evaluation. Circulation, 28, 238.

Chapman, C. B., Fisher, J. N., and Sproule, B. J. (1960). Behavior of stroke volume at rest and during exercise in human beings. J. clin. Invest., 39, 1208.

—, and Fraser, R. S. (1954). Studies on the effect of exercise on cardiovascular function. III. Cardiovascular response to exercise in patients with healed myocardial infarction. Circulation, 7, 347.

Daly, I. de Burch, Ludány, G., Todd, A., and Verney, E. B. (1937). Sensory receptors in the pulmonary vascular bed. Quart J. exp. Physiol., 27, 123.

Donald, K. W., Bishop, J. M., Cumming, G., and Wade, O. L. (1955). The effect of exercise on the cardiac output and circulatory dynamics of normal subjects. Clin. Sci., 14, 37.

Gabe, I. T., Tuckman, J., and Shillingford, J. P. (1962). Determination of relative changes in cardiac output from noncalibrated earpiece dye-dilution curves. Circulat. Res., 11, 405.

Harrison, D. C., Goldblatt, A., Braunwald, E., Glick, G., and Mason, D. T. (1963). Studies on cardiac dimensions in intact, unanesthetized man. Circulat. Res., 13, 448.

Holmgren, A. (1956). Circulatory changes during muscular work in man. Scand. J. clin. Lab. Invest., Suppl. 24.

- Jonsson, B., and Sjöstrand, T. (1960). Circulatory data in normal subjects at rest and during exercise in recumbent position, with special reference to the stroke volume at different work intensities. Acta physiol. scand., 49, 343.

Larsson, G., and Kjellberg, S. R. (1948). Roentgenological heart volume determination with special regard to pulse rate and the position of the body. Acta radiol. (Stockh.), 29, 159.

Malmcrona, R., Cramer, G., and Varnauskas, E. (1963). Hæmodynamic data during rest and exercise for patients who have or have not been able to retain their occupation after myocardial infarction. Acta med. scand., 174, 557.

McMichael, J., and Sharpey-Schafer, E. P. (1944). Cardiac output in man by a direct fick method. Effects of posture, venous pressure change, atropine, and adrenaline. Brit. Heart J., 6, 33.

- , and Shillingford, J. P. (1957). The role of valvular incompetence in heart failure. Brit. med. J., 1, 537.

Mitchell, J. H., Sproule, B. J., and Chapman, C. B. (1958). The physiological meaning of the maximal-oxygen intake test. J. clin. Invest., 37, 538.

Mitchell, J. R. A., and Schwartz, C. J. (1963). The relation between myocardial lesions and coronary artery disease. II. A selected group of patients with massive cardiac necrosis or scarring. Brit. Heart J., $25,1$.

Pentecost, B. L., Irving, D. W., and Shillingford, J. P. (1963). The effects of posture on the blood flow in the inferior vena cava. Clin. Sci., 24, 149.

Reeves, J. T., Grover, R. F., Blount, S. G., Jr., and Filley, G. F. (1961). Cardiac output response to standing and treadmill walking. J. appl. Physiol., 16, 283.

Rushmer, R. F. (1954). Continuous measurements of left ventricular dimensions in intact unanesthetized dogs. Circulat. Res., 2, 14. (1959). Postural effects on the baselines of ventricular performance. Circulation, $20,897$.

- , and West, T. C. (1957). Role of autonomic hormones on left ventricular performance continuously analyzed by electronic computers. Circulat. Res., 5, 240.

Sarnoff, S. J., and Berglund, E. (1954). Ventricular function. I. Starling's law of the heart studied by means of simultaneous right and left ventricular function curves in the dog. Circulation, 9, 706.

_- Brockman, S. K., Gilmore, J. P., Linden, R. J., and Mitchell, J. H. (1960). Regulation of ventricular contraction. Influence of cardiac sympathetic and vagal nerve stimulation on atrial and ventricular dynamics. Circulat. Res., 8, 1108 .

Seldinger, S. I. (1953). Catheter replacement of the needle in percutaneous arteriography. A new technique. Acta radiol. (Stockh.), 39, 368 .

Taylor, S. H., and Shillingford, J. P. (1959). Clinical applications of coomassie blue. Brit. Heart J., $21,497$.

Thomas, M., Malmcrona, R., and Shillingford, J. P. (1964). The accuracy of the photo-electric earpiece technique in the measurement of cardiac output. In preparation. 